\title{
Landscape as a Concept of Space
}

\author{
Ricarda Braun \& Daniel Knitter
}

2016

\section{Introduction $^{1}$}

Exploring landscape as a spatial concept raises more issues than is apparent at first sight. The investigation of the terms landscape and space is an interdisciplinary endeavor, in which the variety of concepts and methods is as widespread as the ambiguity of the terms (ranging from philosophy, sociology, arts, history, and archaeology, to geography and other natural sciences). Abstract concepts of space are not the subject of this article. Instead, as an archaeologist and a geographer, we wish to focus on the interrelation of humans and societies with their natural environment.

In this short contribution, we would like to highlight the advantages of the multifaceted definitions of landscape and space, since they enable and challenge us to be explicit about the assumptions and theoretical background we use in order to investigate both terms. Furthermore, we propose to think of landscape as a concept of space. Using an example from the field of archaeology, the ancient site of Göbekli Tepe, we define space in four different ways. The involvement of these four perspectives strengthens interdisciplinary investigations of landscapes, which integrate different discipline-specific viewpoints in order to achieve more comprehensive explanations and a deeper understanding.

\section{Space}

There are innumerable ways to define or think about space. The common denominator of the discussion is that there is no general definition of space:

\footnotetext{
${ }^{1}$ This work results from a talk by Daniel Knitter, given at the annual conference of the Cluster of Excellence Topoi (Exc 264) on November, 112015 at the Humboldt Universität zu Berlin. It is under review in eTopoi. Journal for Ancient Studies (ISSN 2192-2608) Author affiliations:

Ricarda Braun, German Archaeological Institute; Freie Universität Berlin, Physical Geography, Malteserstr. 74-100, 12449 Berlin, Germany, Email: ricarda.braun@fu-berlin.de.

Daniel Knitter, Christian-Albrechts-Universität zu Kiel, Physical Geography, Ludewig-MeynStr. 14, 24118 Kiel, Germany, Email: knitter@geographie.uni-kiel.de.
} 
every definition depends on the research context and the ontological as well as epistemological viewpoint of the individual researcher.

We also think that an all-encompassing definition is neither possible nor necessary. It is the combination and integration of different perspectives on space that help us to gain a better understanding of the complex research object and the way how it is investigated by the different researchers.

It is not our intention to present the conceptual history of the term space. Instead, we wish to present four different approaches to space that provide a broad overview of the most common perspectives through the course of its development. The concepts mentioned have been summarized and described before by Wardenga ${ }^{2}$ for didactic purposes at German-speaking schools.

\section{Space as container}

In a positivistic sense, spaces are understood as containers or boxes that contain specific aspects of the physical material world. Spaces are individual entities that exist in reality. Container spaces are (a) a coupled system of natural and anthropogenic factors, (b) the results of processes that have shaped the natural environment, and (c) a playground for human action and intervention. ${ }^{3}$ This view, which aims to be comprehensive and holistic, was popularized in the early twentieth century by Hettner and his Länderkundliches Schema, ${ }^{4}$ as well as by Sauer and his Landscape School. ${ }^{5}$

\section{Space as system of relations and connections}

The second perspective defines space as a system of relations and connections between the locations of material objects. Location and distance, as well as the relationship of both, are the most important aspect in systematic investigations following this definition of space, since they cause and are caused by a certain societal reality. ${ }^{6}$ Examples of research approaches following this definition of space are the central place theory of Walter Christaller ${ }^{7}$ and its extensions by August Lösch. ${ }^{8}$

\footnotetext{
${ }^{2}$ Wardenga 2002.

${ }^{3}$ Wardenga 2002: 5.

${ }^{4}$ E.g., Hettner 1907a, Hettner 1907b.

${ }^{5}$ Sauer 2008.

${ }^{6}$ Wardenga 2002: 5

${ }^{7}$ Christaller 1933.

${ }^{8}$ Losch 1954.
} 


\section{Space as product of human perception}

In the third perspective, spaces are no longer recognized as objective entities but as something related to and defined by human perception: people's perceptions guide their actions and produce space. ${ }^{9}$ An illustrative example is the study by Weichhart, ${ }^{10}$ who investigated how people's evaluation of their environment influenced the development of settlements. In his model, nature is present only through a filter of perception - the latter being a product of societal circumstances.

\section{Space as construct}

Lastly, in a fourth perspective, space is seen as the product of human agency; spaces are social constructs. This perspective questions which individuals are communicating about space and hence producing and reproducing it: ${ }^{11}$ What are the circumstances and reasons for communication? What are the specific interests? To whom is the communication being directed?

The different perspectives or definitions of space mirror the general conceptual history of this term during the last 150 years. The container space is based on a holistic and teleological viewpoint, common for positivistic research approaches at the turn of the twentieth century. During the course of the quantitative revolution that followed, the laws that govern spatial phenomena became more focused. Researchers used modeling approaches in an attempt to gain new insight into the reasons for spatial patterning and organization. Nevertheless, the focus was no longer holistic, since these models concentrated on specific phenomena such as central places, economic networks, and diffusion processes. There was increasing criticism of the modeling approaches, which were seen as too deterministic, too mechanistic, and/or too simplistic. A deeper understanding was sought of the relationship between humans, their spatial organization, and their relation to the environment. New ways of defining and investigating space were developed that were based on agency. The level of abstracting space and spatial relations ranged from general descriptions of perceptions in certain groups to complete constructions of space based on individual intentions.

Of course, the history of science is not a story of the continuous accumulation of knowledge. Therefore, the four perspectives on space have to be seen as complementary; they focus on different questions and rely on different methods and data (Figure 1).

For our integrative viewpoint, we state that space is defined by relations and connections between specific elements in an area. Its specific scope, i.e., relation of what, depends on the research question. We saw that each of the four

\footnotetext{
${ }^{9}$ Wardenga 2002: 5 .

${ }^{10}$ Weichhart 1978.

${ }^{11}$ Wardenga 2002: 5 .
} 


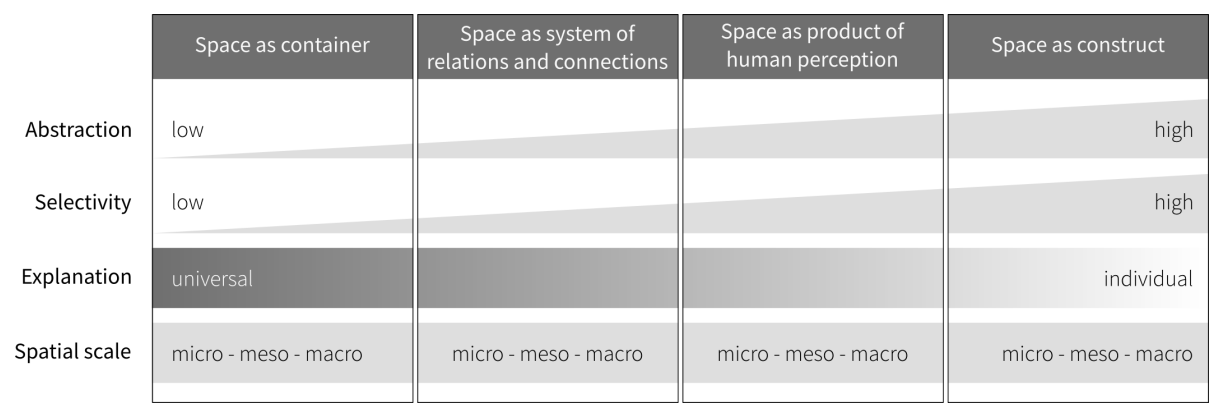

Figure 1: Different concepts of space

perspectives on space has its blind spots, which become obvious and can be tackled when all four perspectives are integrated in the investigation of a research question. This integrative approach helps us to explain justified restrictions on our own viewpoint and to be explicit about the blind spots of the investigation.

\section{Landscape}

Now that we have framed the concept of space, we are able to employ it in a specific context. Even more than space, landscape is a common-sense term. A view on the history of the term helps to illustrate how this common sense meaning developed.

There is documented usage of lantschaft or lantscaf as a term in $830 \mathrm{CE}$ for a politically defined area or territory. ${ }^{12}$ Later on, Landschaft referred to people living in a certain region as defined by shared legislation, e.g., the Landschaft of Basel. ${ }^{13}$ Besides these regionally oriented meanings of the term, landscape began to be used in the sixteenth century as a terminus technicus of painters, most prominently by those from the Netherlands, where landschap was an artistic term that referred to the specific composition of natural and cultural elements in a scene. ${ }^{14}$ It was a time when a certain mode of viewing a landscape developed, when the physiognomy of nature created landscapes based on an painter's idea of what the environment should look like.

The two views merged at the beginning of the twentieth century and created the foundation for new traditions of thought. These traditions integrate the regionally oriented thinking concerning nature and culture with the focus on the aesthetic components and necessities of landscapes. ${ }^{15}$ In the common-sense view, then, landscapes are seen as an area that describes a certain spatial extent and is

\footnotetext{
12 Schenk 2002: 6 .

${ }^{13}$ Schenk 2002: 7 .

${ }^{14}$ See Ossing et al. 2001.

${ }^{15}$ See Schenk 2002: 7.
} 
comprised of natural and cultural features that implicitly incorporate a temporal dimension and whose value or quality is determined by societal circumstances. ${ }^{16}$

The scientific view on landscape is sometimes very close to this common-sense understanding; the two modes of comprehension are nearly congruent, for example, in traditional geography, with its container space. There are aesthetic and beautiful landscapes, devastated landscapes, industrial landscapes, etc. The descriptive approach in this tradition aims to identify all features of a specific area and illustrates their integration in order to create the picture of the specific landscape.

Comparable to the development of definitions for the term space, the conceptual history of the term landscape features numerous debates about its proper understanding and methods of investigation. It is common to all approaches that they do not intend to be holistic but focus on specific aspects of culture, society, or nature. Many excellent works present, summarize, and discuss the characteristics and development of these approaches. ${ }^{17}$

As a result, the term landscape is polysemous; ${ }^{18}$ its meaning is ambiguous in ordinary language as well as in science. The diversity of ways to access and investigate landscape has been shown by Gailing and Leibenath, ${ }^{19}$ who discuss opposing pairs of ways that landscape is investigated:

- holistic vs. elementaristic

- normative vs. descripitive

- individual vs. universal

- subjectivistic vs. objectivistic

- positivistic and essentialistic vs. reflexive and constructivistic

- landscape as image vs. landscape as part of the surface of the earth

- landscape as research object vs. landscape as way of seeing

- landscape as lived space vs. landscape as observed space

It is obvious that the definition depends on the individual point of view about what landscape is and how it can be analyzed. Two strands aiming to solve this difficulty can be identified. On the one side are those wanting an unambiguous definition of the term. Since these advocates stem from different scientific backgrounds, there are continuous debates about the most appropriate definition of landscape. On the other side are those who see an opportunity in the heterogeneity itself. For them the diverse ways of accessing and understanding landscape are an essential driving force to integrate the different research approaches of investigating landscape. ${ }^{20}$ We believe that only the latter approach is fruitful in an interdisciplinary perspective.

\footnotetext{
${ }^{16}$ Kühne 2015: 44-45.

${ }^{17}$ E.g., Hard 2002, Hokema 2012, Ipsen 2006, Ingold 1993, Johnson 2007, Kaufmann 2005, Kühne et al. 2015, Küster 2012, Legler 2012, Martini \& Chesworth 2010, Schenk 2002, Schmithüsen 1964, Tilley 1994, Wylie 2007.

${ }^{18}$ Hard 1969.

${ }^{19}$ Gailing \& Leibenath 2011.

${ }^{20}$ Jessel 2005: 582
} 
One field characterized by an interdisciplinary perspective is landscape archaeology. In this discipline, archaeology and physical geography work together to understand the interrelation of humanity and nature in (pre-)history. It is not surprising that difficulties arise in this collaboration because of the ambiguous definitions of landscape. We aim to tackle them by stating the different definitions explicitly and then trying to integrate them by using a soft definition of landscape as resulting from the different perspectives of space.

\section{Landscape as seen in physical geography}

Looking at the usage of the term landscape in physical geography, one recognizes that it has not been influenced by the conflicts about the definition of the term and its applicability. Like the understanding of space at the turn of the twentieth century, landscape is seen in container perspective as a real entity. This entity is composed of different interdependent and causally related spheres that form a hierarchy. The exact number and naming of the defined spheres differ between authors. The least common denominator is the triad of the physical, biological, and cultural spheres. ${ }^{21}$ The different spheres can be represented as layers which are directly analyzable (e.g., using a Geographic Information System). Such representation is possible because every object refers to the real euclidean geographic space: when a physical geographer talks about "the landscape of the river Rhine near Cologne," she is referring to elements of nature as well as elements shaped by and comprised of culture. ${ }^{22}$

\section{Landscape as seen in archaeology and human geography}

The historical dynamics of the definition of the term landscape in the humanities and social science disciplines of archaeology and human geography, by contrast, are very dynamic. To put it briefly, one can say that the focus switched from etic to emic.

The leading paradigm in the early years was comparable to that of physical geography. Landscape was seen as a real entity, separated into natural and cultural elements, and spatial aspects were comprehended as the most important. The location, distribution, and patterns of sites, artifacts, and people were compared and integrated with the background information of the natural environment. ${ }^{23}$ This approach (also called the ecological approach for its strong connection to the spatial and natural conditions) became very fashionable in the course of the processualistic movement and the introduction of computational methods.

\footnotetext{
${ }^{21}$ See, e.g., Gray 2009.

${ }^{22}$ Küster 2012: 145-148.

${ }^{23}$ Some important representatives of geography from this strand are Hettner 1907b, Schlüter 1906, Sauer 2008, and Troll 1950; important archaeologists are Wahle 1920 and Clark 1948; in this regard see also Legler 2012.
} 
Concepts and methods were mostly developed in the so-called New Geography movement ${ }^{24}$ and adapted and modified in terms of processual archaeology. ${ }^{25}$

These views were criticized for their simplicity and their inability to take the individual component of humans into account. But this understanding changed, especially during the post-processual movement, when landscape was no longer conceived as a real entity but a product of human perception and construction. In human geography landscapes are the comprehensive result of human action that constitute a complex societal archive. ${ }^{26}$ The spatial aspect remains, since landscapes mirror distinctive characteristics of specific places and regions. Nevertheless, space can no longer be described as being absolute, since social groups or individuals may have different definitions or understandings of landscape. This leads to a multitude of landscapes that exist simultaneously in one place. ${ }^{27}$ The perspective has thus shifted from etic to emic.

The emic perspective is at the heart of the modern definition of landscape in landscape archaeology as well. The lifeworld of humans creates their landscape; hence, landscape is a social construct. ${ }^{28}$ Following this definition, an etic perspective does not describe landscape but environment. For Gramsch, ${ }^{29}$ landscape is a framing term: it is a structural phenomenon characterized by the dialectic of space and place and a physical phenomenon of a nature-culture space that is continuously changed by humans.

In the modern definitions of landscape, the common denominator is that landscape is a constructivistic concept where humans constitute and create their landscape. Landscape is a cultural phenomenon that is investigated from an emic perspective. Nevertheless, aside from these general aspects, the definitions differ, and so do the opinions about what methods of landscape investigations should implement and what insights they can provide. ${ }^{30}$

In summary, we can state that landscape is something composed of and created by humanity and nature and is defined by the specific research question.

\section{Landscape as concept of space}

As we have seen, the terms landscape and space are both used polysemously and ambiguously. In thinking about landscape as a concept of space, we want to benefit from this diversity of viewpoints rather than try to create new boundaries.

\footnotetext{
${ }^{24}$ E.g., Haggett \& Chorley 1969.

${ }^{25}$ E.g., Clarke 1978.

${ }^{26}$ Knox \& Marston 2008: 377.

${ }^{27}$ Knox \& Marston 2008: 379-381.

${ }^{28}$ Meier 2012: 509.

${ }^{29}$ Gramsch 2003: 48.

${ }^{30}$ There is a very broad variety of concepts and theories. An inexhaustive list for geography: Cosgrove 2006, Klüter 1986, Soja 2001, Tuan 1974, Werlen 1997; for archaeology we find Gramsch 2003, Meier 2012, and Tilley 1994 most inspiring.
} 
For instance, the four different perspectives on space are fruitful in landscape archaeological research because they force us to state explicitly in which circumstances we will take an emic or an etic perspective, as well as help us to communicate the unavoidable blind spots of our chosen research approach. The combination of both terms, landscape and space, in the frame of landscape as a concept of space thus ensures the broad understanding of the research object and an appropriate handling of the complex interrelations of humanity and nature not just regarding the subject itself, but also in terms of the chosen scientific approach.

\section{An example of thinking in terms of landscape as a concept of space: Göbekli Tepe}

The ancient hilltop site Göbekli Tepe, located in southeastern Turkey, is considered one of the most significant cultic centers of its time. The site dates to the period of the Pre-Pottery Neolithic, at the transition from hunter-gatherer societies to a more sedentary way of life.

If we are to think about the landscape around Göbekli Tepe from a container perspective, i.e., from an etic point of view, we will be looking for the structural coupling of anthropogenic effects and geofactors, whereby the site and its surroundings are understood as a physical and bounded space. Landscape as a concept of container space is a collection, description, and interconnection of all accessible elements of the area.

Such an inventory brings up questions about the how, why, and where of the natural characteristics and humanity's utilization of these. Such questions could focus on the climatic conditions, bedrock material, available soils, water availability, topographic features, vegetation, or other aspects. Göbekli Tepe, during its time of occupation, was situated at the top of a ridge - more precisely, it is situated on a limestone plateau with no direct access to water, with the closest springs at the foot of this plateau ${ }^{31}$ - at the northern edge of a fertile plain characterized by a diverse range of ecological habitats with xerophyllus light vegetation and varied game populations. ${ }^{32}$

This consideration leads to questions about people's spatial demands relating to the natural environment. Was the position on top of the plateau deliberately chosen because of its environmental conditions, such as the topographic position and the ubiquitously available bedrock that was quarried to erect building structures? ${ }^{33}$ Was the scarcity of available water consciously taken into account, or was it required of the site as a place of ritual?

The container space perspective also prompts an examination of the settlement structure and economic behavior. A question frequently raised within this

\footnotetext{
${ }^{31}$ Schmidt 2011: 41.

${ }^{32}$ Neef 2003: 13.

33 Schmidt 2010-1: 16.
} 
framework refers to the causal effect between the climate change at the Pleistocene/Holocene transition and the so-called Neolithic Revolution. ${ }^{34}$ Applying this environmentally deterministic mode of explanation to Göbekli Tepe leads to the question of whether Göbekli Tepe was abandoned due to the changing climatic conditions that allowed new settlement and economic structures to develop, which in turn led to a change in spatial demands and organization (e.g., of the natural environment).

We can investigate landscapes as a concept of space, on the other hand, by focusing on the system of relations and connections between the location of material objects. Again, landscape is seen from an etic perspective, with attention to the interconnections of specific, intentionally selected elements in an area. Space is reduced to these interconnections, and a comprehensive description and investigation of the areal features and elements is not important.

Applying this perspective to Göbekli Tepe, we focus on its position within the network of Pre-Pottery Neolithic sites, with an aim of explaining how interactions or exchange between these sites worked and which network functions were fulfilled by Göbekli Tepe. Did the hilltop serve as a place of ritual because of its (previous) role as a central site within the exchange network of hunter groups? In other words, did several hunter groups use the site as a venue? ${ }^{35}$ A specific example of such regional exchanges are the T-shaped pillars ${ }^{36}$ at Göbekli Tepe: megaliths that were erected in several circles, probably for ritual use. Such pillars can also be found at additional sites in the surrounding area. ${ }^{37}$ This raises the question of how material culture was diffused, and whether such diffusion was accompanied by a transfer of ritual practices or concepts. Employing graphtheoretical methods, we can calculate network graphs connecting the hitherto known sites. Based on these calculations Göbekli Tepe can be considered as one central hub within these networks, illustrating its central role in the exchange of knowledge and ideas (Figure 2). If we include the issues mentioned with the first perspective of space, we could also consider whether the dynamics of social networks shaping Göbekli Tepe changed because of a changing demand for space. We must examine whether the exchange networks between huntergatherer groups are reflected in the material culture of the T-shaped pillars, which declined along with the rise of newly established economic structures.

When taking an emic perspective, we can investigate landscapes as a concept of space that is defined by and the result of human perception. We are therefore interested in the meaning attached to locations and to people's environs. Regarding our example, we would want to know the perception of Göbekli Tepe's position in its environmental context, and moreover, what ideas were held within the hunter-gatherer groups about ritual landscape. Göbekli Tepe is outstanding from a present-day perspective because of its insularity, which assures high

\footnotetext{
${ }^{34}$ E.g., Willcox et al. 2009; Haldorsen et al. 2011.

${ }^{35}$ Schmidt 2010a: 18; Dietrich et al. 2012.

${ }^{36}$ Watkins 2008.

${ }^{37}$ Çelik 2015.
} 


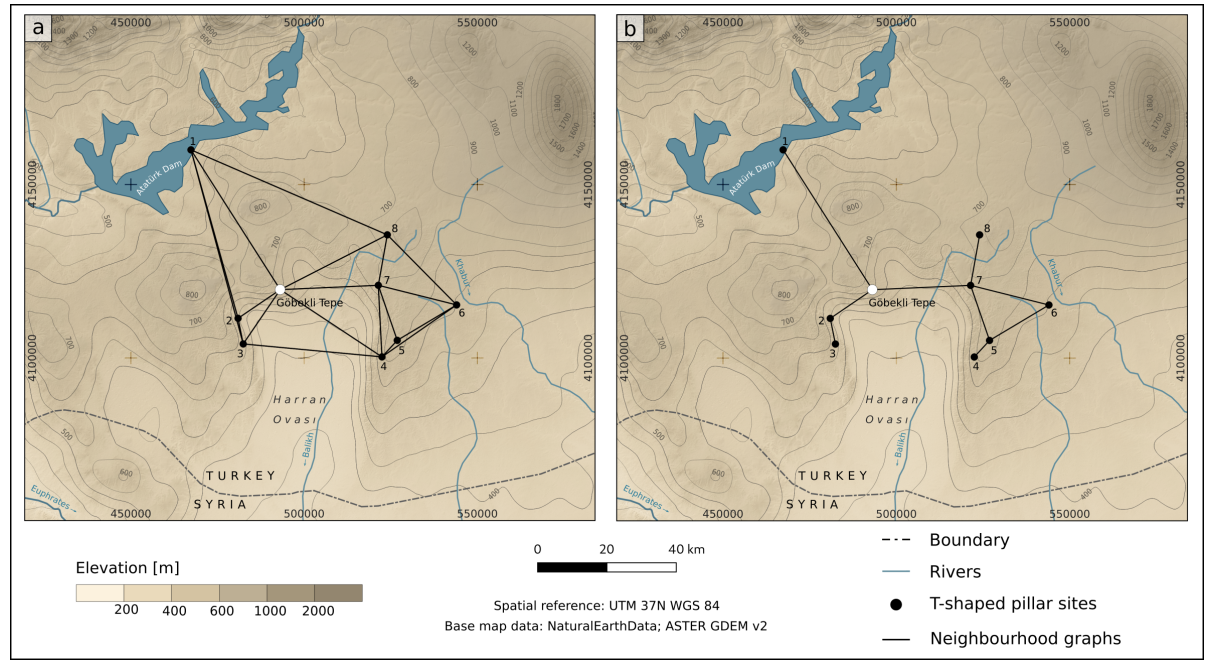

Figure 2: Potential network of interaction between Pre-Pottery Neolithic sites with T-shaped pillars. The central position of Göbekli Tepe becomes obvious. (a) Delaunay; (b) Gabriel graph; Sites according to the numbers: (1) Nevalı Çori (2) Urfa Yeni Yol/Yeni Mahalle (3) Hamzan Tepe (4) Harbetsuvan Tepesi (5) Karahan Tepe (6) Sefer Tepe (7) Kurt Tepesi (8) Taşlı Tepe; calculation conducted in R using sp, rgdal, and spdep packages (Bivand et al. 2015, Bivand \& Piras 2015, Bivand 2013, Pebesma 2005, R_core_team 2016) 
visibility as well as the protection of the site. Is it valid to assume that the Pre-Pottery Neolithic societies assessed the site similarly? With this in mind, a subsequent investigation should then review which factors led to the choice of location. Even though this question is linked to the first approach, at this point the mere existence of environmental factors is less important than how they were perceived, and how this perception can be reconstructed using material culture. We can transfer this view to questions concerning the environmental potential of the region as well. The Harran Ovası, a fertile plain south of Göbekli Tepe, offered a range of resources to hunter-gatherers. How did people perceive these? We can follow the theory of affordances by Gibson. ${ }^{38}$ Affordances are understood as all offerings of nature or possibilities for action that invite or demand a specific behavior and always depend on individual perception. ${ }^{39}$ While various offerings were already recorded in the first approach, such as the topographic position or the environmental potential of the surroundings, the third approach enables us to comprehend the perception of these offerings.

This perceptive and behavioral geographic approach can be extended using a perspective that focuses on agency. This allows us to investigate landscapes as a concept of space constructed by human thought and materialized by human agency. Based again on the theory of Gibson, affordances can be seen as a driver for actions. We can assume that space at Göbekli Tepe was symbolically staged by the enclosures of T-shaped pillars and theoretically constructed through ritual practices. The circular structures consist of ten or more pillars forming the outer enclosures and a pair of two prominently positioned pillars in the center. The T-shaped form of the pillars and the relief surfaces indicate an anthropomorphic nature. ${ }^{40}$ Hence, we might hypothesize that the pair of megaliths did represent specific persons in the communities. The question is whether power structures and a coherent spatial understanding were stabilized by means of the enclosures, and whether they were built to achieve specific effects within the inner group or among communities. Additionally, we examine whether the enclosures depicted a physically present space or a constructed space. Archaeological evidence suggests that the enclosures were possibly intentionally backfilled what might indicate a transition in spatial construction. ${ }^{41}$ Furthermore, the surfaces of the pillars contain relief carvings of animals. Gheorgiu ${ }^{42}$ has assumed that this iconography cartographically depicts the landscape, so that the animal shall be seen "in its relationship with a specific place, which is its habitat. [...] Consequently the iconography would not be zoomorphic, but topomorphic." 43

Clearly, investigations of sites like Göbekli Tepe necessitate an approach that integrates the emic and etic perspective. Such a challenge can be solved by employing the four different views on space, since they show how the specific

\footnotetext{
${ }^{38}$ Gibson 2015.

${ }^{39}$ Gibson 2015: 119-35.

${ }^{40}$ Schmidt 2012: 110.

${ }^{41}$ Schmidt 2010b: 242 .

${ }^{42}$ Gheorgiu 2015.

${ }^{43}$ Gheorghiu 2015: 67.
} 
site and landscape will change when targeted from various directions. This leads to a more comprehensive understanding of the research object and strengthens interdisciplinary communication.

\section{Conclusions}

This short contribution sketches how viewing landscape as a concept of different perspectives on space can integrate the ambiguity of the terms landscape and space, as well as the broad variety of available theories. For instance, space and landscape can be seen from an etic or emic perspective; they can be regarded as something real or abstract and investigated aiming to be holistic or focusing on specific aspects. All of these different scientific perspectives produce important results to improve the understanding of the complex of meaning around landscape. At the same time, they are restricted by the disciplinary training of the researcher, the scope of the applied methods, and the theoretical viewpoint chosen. Interdisciplinary collaboration can broaden the disciplinary foci and offers important contributions to the results achieved during the research process. The approach we have presented of seeing landscape as a concept of space, where space is seen from different perspectives, supports interdisciplinary collaboration. Hypotheses and points of view become explicit when the concept of how landscape is viewed is stated. The overlapping borders of the different perspectives on space show direct connections to supplement and complement the research approach and state new questions. Finally, we can make research in landscape archaeology more comprehensive and efficient by integrating different approaches from various disciplines, disciplines that can find a shared language in investigating landscapes as a concept of space.

\section{References}

Bivand, Roger, Edzer Pebesma, and Virgilio Gomez-Rubio. 2013. Applied Spatial Data Analysis with R. Springer, NY. http://www.asdar-book.org/.

Bivand, Roger, and Gianfranco Piras. 2015. "Comparing Implementations of Estimation Methods for Spatial Econometrics." Journal of Statistical Software 63 (18): 1-36. http://www.jstatsoft.org/v63/i18/.

Bivand, Roger, Tim Keitt, and Barry Rowlingson. 2015. Rgdal: Bindings for the Geospatial Data Abstraction Library. https://CRAN.Rproject.org $/$ package $=$ rgdal.

Çelik, Bahattin. 2015. "New Neolithic Cult Centres and Domestic Settlements in the Light of Urfa Region Surveys." Documenta Praehistorica 42: 352-64. 
Christaller, Walter. 1933. Die Zentralen Orte in Süddeutschland - Eine ökonomisch-Geographische Untersuchung über Die Gesetzmäßigkeiten Der Verbreitung Und Entwicklung Der Siedlungen Mit Städtischer Funktion. Jena: Gustav Fischer.

Clark, J. G. D. 1948. Von Der Wildheit Zur Zivilisation. Vienna: Neues Österreich.

Clarke, David L. 1978. Analytical Archaeology. 2nd ed. University Paperbacks 428. London: Methuen.

Cosgrove, Denis. 2006. "Modernity, Community and the Landscape Idea." Journal of Material Culture 11 (1-2): 49-66. doi:10.1177/1359183506062992.

Dietrich, Oliver, Manfred Heun, Jens Notroff, Klaus Schmidt, and Martin Zarnkow. 2012. "The Role of Cult and Feasting in the Emergence of Neolithic Communities. New Evidence from Göbekli Tepe, South-Eastern Turkey." Antiquity 86 (333): 674-95.

Gailing, Ludger, and Dr. Markus Leibenath. 2011. "Von Der Schwierigkeit, „Landschaft” Oder „Kulturlandschaft" Allgemeingültig Zu Definieren." Raumforschung und Raumordnung 70 (2): 95-106. doi:10.1007/s13147-011-0129-8.

Gheorghiu, Dragoş. 2015. "A River Runs Through It: The Semiotics of Göbekli Tepe's Map (An Exercise of Archaeological Imagination)." In Rivers in Prehistory: Edited by Andrea Vianello, edited by Andrea Vianello. Archaeopress Archaeology. Oxford: Archaeopress.

Gibson, James J. 2015. The Ecological Approach to Visual Perception. New York; Hove, England: Psychology Press.

Gramsch, Alexander. 2003. "Landschaftsarchäologie-ein Fachgeschichtlicher überblick Und Ein Theoretisches Konzept." In Landschaftsarchäologie und Geographische Informationssysteme. Archäoprognose Brandenburg I. Symposium Landschaftsarchäologie und Geographische Informationssysteme-Prognosekarten, Besiedlungsdynamik und Prähistorische Raumordnungen: , edited by Jürgen Kunow and Johannes Müller, 15:35-54. Wünsdorf: Brandenburgisches Landesamt für Denkmalpflege und Archäologisches Landesmuseum.

Gray, Murray. 2009. "Landscape: The Physical Layer." In Key Concepts in Geography, edited by N. J. Clifford, Sarah L. Holloway, Stephen P. Rice, and Gill Valentine, 2nd ed., 265-85. Los Angeles: Sage.

Haggett, Peter, and Richard J. Chorley. 1969. Network Analysis in Geography. Explorations in Spatial Structure 1. New York: St. Martin's Press.

Haldorsen, Sylvi, Hasan Akan, Bahattin Çelik, and Manfred Heun. 2011. "The Climate of the Younger Dryas as a Boundary for Einkorn Domestication." Vegetation History and Archaeobotany 20 (4): 305-18.

Hard, Gerhard. 1969. "Das Wort 'Landschaft' und sein Semantischer Hof: Zu Methode u. Ergebnis eines linguistischen Tests." Wirkendes Wort 19: 3-14. 
. 2002. Landschaft und Raum. Aufsätze zur Theorie der Geographie. Vol. 1. Osnabrücker Studien zur Geographie, vol. 22. Osnabrück: Universitätsverlag Rasch.

Hettner, Alfred. 1907a. "Die Geographie Des Menschen." Geographische Zeitschrift 13 (8): 401-25. 1907b. Grundzüge Der Länderkunde. Leipzig: Otto Spamer.

Hokema, Dorothea. 2012. Landschaft Im Wandel?: Zeitgenössische Landschaftsbegriffe in Wissenschaft, Planung und Alltag. Wiesbaden: Springer-Verlag.

Ingold, Tim. 1993. "The Temporality of the Landscape." World Archaeology 25 (2): $152-74$.

Ipsen, Detlev. 2006. Ort Und Landschaft. Wiesbaden: VS Verlag für Sozialwissenschaften.

Jessel, Beate. 2005. "Landschaft." In Handwörterbuch der Raumordnung, edited by Ernst-Hasso Ritter, 579-86. Hannover: Akademie für Raumforschung und Landesplanung.

Johnson, Matthew. 2007. Ideas of Landscape. Wiley-Blackwell.

Kaufmann, Stefan. 2005. Soziologie der Landschaft. Wiesbaden: VS Verlag für Sozialwissenschaften.

Klüter, Helmut. 1986. Raum Als Element Sozialer Kommunikation. Gießen: Gießener geographische Schriften.

Knox, Paul L., and Sallie A. Marston. 2008. Humangeographie. Places and Regions in Global Context. 4th ed. Heidelberg: Spektrum, AkadVerl.

Kühne, Olaf. 2015. "The Evolution of the Concept of Landscape in German Linguistic Areas." In Landscape Culture - Culturing Landscapes, edited by Diedrich Bruns, Olaf Kühne, Antje Schönwald, and Simone Theile, 41-66. Wiesbaden: Springer Fachmedien Wiesbaden.

Kühne, Olaf, Krzysztof Gawroński, and Józef Hernik, eds. 2015. Transformation und Landschaft: Die Folgen Sozialer Wandlungsprozesse auf Landschaft. Wiesbaden: Springer.

Küster, Hansjörg. 2012. Die Entdeckung Der Landschaft: Einführung in Eine Neue Wissenschaft. Munich: Beck.

Legler, Kathrin. 2012. "Der Archäologische Landschaftsbegriff aus Wissenschaftsgeschichtlicher Perspektive-ein Überblick." Archäologische Informationen 35: 39-52.

Lösch, August. 1954. Economics of Location. Translated by William H. Woglom. New Haven, London: Yale University Press.

Martini, I. Peter, and Ward Chesworth, eds. 2010. Landscapes and Societies: Selected Cases. 1st ed. Springer. 
Meier, Thomas. 2012. "'Landscape,' 'Environment' and a Vision of Interdisciplinarity." In Landscape Archaeology Between Art and Science, edited by Sjoerd J Kluiving and Erika Guttmann-Bond, 503-14. Amsterdam University Press.

Neef, Reinder. 2003. "Overlooking the Steppe-Forest: A Preliminary Report on the Botanical Remains from Early Neolithic Göbekli Tepe (Southeastern Turkey)." Neo-Lithics 2 (03): 13-16.

Ossing, Franz, Jörg F. W. Negendank, and Rolf Emmermann. 2001. "Wie entsteht Landschaft?" In Katalog zur Ausstellung: Die "Kleine Eiszeit": Holländische Landschaftsmalerei im 17. Jahrhundert, edited by Gemäldegalerie, Staatliche Museen zu Berlin, 26-40. Bilder im Blickpunkt. Berlin: Staatliche Museen zu Berlin, Preussischer Kulturbesitz.

Pebesma, Edzer, and Roger Bivand. 2005. "Classes and Methods for Spatial Data in R." $R$ News 5 (2): 9-13.

R Core Team. 2016. R: A Language and Environment for Statistical Computing. Vienna, Austria: R Foundation for Statistical Computing. https://www.Rproject.org/.

Sauer, Carl O. 2008. "The Morphology of Landscape." In The Cultural Geography Reader, edited by Timothy Oakes and Patricia Price, 96-104. London, New York: Routledge.

Schenk, Winfried. 2002. "'Landschaft' und 'Kulturlandschaft' - 'Getönte' Leitbegriffe für aktuelle Konzepte geographischer Forschung und räumlicher Planung." Petermanns Geographische Mitteilungen 146 (6): 6-13.

Schlüter, Otto. 1906. Die Ziele der Geographie des Menschen. Munich, Berlin: R. Oldenbourg.

Schmidt, Klaus. 2010a. "Göbekli Tepe - Der Tell als Erinnerungsort." In Leben auf dem Tell als soziale Praxis: Beiträge des internationalen Symposiums in Berlin vom 26. -27. Februar 2007, edited by Svend Hansen, 13-23.

_ 2010b. "Göbekli Tepe - the Stone Age Sanctuaries. New Results of Ongoing Excavations with a Special Focus on Sculptures and High Reliefs." Documenta Praehistorica 37: 239-56.

. 2011. "Göbekli Tepe." In The Neolithic in Turkey: New Excavations 83 New Research, edited by Nezih Başgelen, Mehmet Ozdoğan, and Peter Ian Kuniholm, 3rd ed., 2:41-38. Galatasaray, Istanbul: Archaeology \& Art Publications.

- 2012. Göbekli Tepe: A Stone Age Sanctuary in South-Eastern Anatolia. Berlin: Ex Oriente.

Schmithüsen, Josef. 1964. Was ist eine Landschaft? Vol. 9. Erdkundliches Wissen. Wiesbaden: Steiner.

Soja, Edward W. 2001. Postmetropolis: Critical Studies of Cities and Regions. Oxford: Blackwell. 
Tilley, Christopher. 1994. A Phenomenology of Landscape: Places, Paths and Monuments. Oxford: Berg Publishers.

Troll, Carl. 1950. "Die Geographische Landschaft und ihre Erforschung." In Studium Generale, edited by K. H. Bauer, L. Curtius, H. v. Einem, F. Ernst, H. Friedrich, W. Fucks, E. Hoffmann, et al., Issue 4/5 (3). Berlin, Heidelberg: Springer Berlin Heidelberg.

Tuan, Yi-Fu. 1974. Topophilia: A Study of Environmental Perception, Attitudes, and Values. Englewood Cliffs, NJ: Prentice-Hall.

Wahle, Ernst. 1920. "Die Besiedlung Südwestdeutschlands in Vorrömischer Zeit nach ihren natürlichen Grundlagen." Bericht der Römisch-Germanischen Kommission 12: 1-76.

Wardenga, Ute. 2002. "Ute Wardenga: Räume der Geographie - Zu Raumbegriffen im Geographieunterricht."

Watkins, Trevor. 2008. "Supra-Regional Networks in the Neolithic of Southwest Asia." Journal of World Prehistory 21 (2): 139-71. doi:10.1007/s10963-008-9013$\mathrm{z}$.

Weichhart, Peter. 1978. "Naturraumbewertung und Siedlungsentwicklung. Das räumliche Wachstum ausgewählter Siedlungen des politischen Bezirkes Braunau a. I. im Vergleich mit dem Naturraumpotential ihrer Standorte." Oberösterreichische Heimatblätter 32: 171-208.

Werlen, Benno. 1997. Gesellschaft, Handlung und Raum: Grundlagen handlungstheoretischer Sozialgeographie. 3., rev. ed. Stuttgart: Steiner.

Willcox, G., R. Buxo, and L. Herveux. 2009. "Late Pleistocene and Early Holocene Climate and the Beginnings of Cultivation in Northern Syria." The Holocene 19 (1): 151-58. doi:10.1177/0959683608098961.

Wylie, John. 2007. Landscape. Annotated edition. Routledge. 